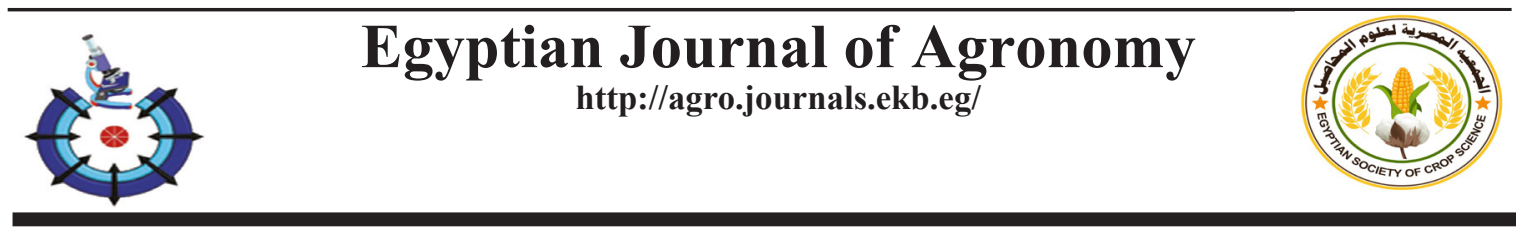

\title{
Role of Zinc on Drought Tolerance in Some Wheat (Triticum aestivum L.) Cultivars under Reduced Soil Water
}

Rasha E. Mahdy ${ }^{(1) t}$, Kotb A. Farghali ${ }^{(2)}$

(l) Agronomy Department, Faculty of Agriculture, Assiut University, Assiut, Egypt;

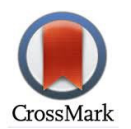

${ }^{(2)}$ Department of Botany and Microbiology, Faculty of Science, Assiut University, Assiut, Egypt.

\begin{abstract}
D ROUGHT is a serious abiotic stress affects crop production in Egypt and worldwide. Two experiments were carried out under drought stress and normal irrigation during the seasons of 2018/19 and 2019/20 to study the effect of foliar application of $\mathrm{Zn}$ to alleviate drought stress. The soil texture is clay. The genetic materials were three Egyptian cultivars; Sakha 69, Giza 68 and Gemmieza 11. The levels of foliar spray of zinc oxide were 500ppm, 250 ppm, water and control (no treatment), sprayed two weeks before and at anthesis. Mean squares of the combined data was significant $(\mathrm{P} \leq 0.01)$ for $\mathrm{Zn}$ levels and for yield traits except for spike length. The differences among cultivars were significant $(\mathrm{P} \leq 0.01)$ except for yield under irrigation. This confirms the concept of "selection for yield under stress is better than under favorable environment". The traits plant height $(\mathrm{PH})$, number of spikes/plant (NS/P), biological yield/plant (BY/P), grain yield/plant (GY/P) and 100GW showed the best performance at the higher $\mathrm{Zn}$ level 500ppm. Water deficit exerted negative effects on $\mathrm{RWC} \%$ and chlorophyll. The reduction \% (the difference between irrigation and drought stress relative to irrigation performance) in all traits was the lowest at $500 \mathrm{ppm}$ of $\mathrm{Zn}$ and increased ascendingly by decreasing the Zn level. Sakha 69 significantly showed the best performance for PH, NS/P and $\mathrm{BY} / \mathrm{P}$ under both, drought stress and normal irrigation. It could be concluded that $\mathrm{Zn}$ foliar application alleviated drought stress, and Sakha 69 was the most stable cultivar in GY/P and gave the best performance under drought stress.
\end{abstract}

Keywords: Chlorophyll, Drought stress, RWC\%, T. aestivum L., Zn foliar application.

\section{Introduction}

Drought is one of the main limiting abiotic factors of wheat production in arid and semiarid environments. Drought affects growth and plant development as considered a challenge for agricultural researchers and plant breeders (Mahpara et al., 2015; Nezhadahmadi et al., 2013). Therefore, drought should be highly preferred in the future wheat improvement programs. Raising productivity of a crop depends on the availability of nutrients during its life cycle. Zinc deficiencies cause agronomic problems, particularly in cereals (Moreno-Lora \& Delgado, 2020).Zinc is a precursor of plant growth hormones (auxin), proteins and is required in sugar consumption. Root development, carbohydrate and chlorophyll formation are also dependent on zinc. $\mathrm{Zn}$ is a regulatory co-factor and structural constituent in proteins and enzymes involved in many biochemical pathways (Alloway, 2009; Cakmak et al., 2017). The presence of some micronutrients needed for plant growth may alleviate the effect of dehydration. Interestingly $\mathrm{Zn}, \mathrm{B}$, and $\mathrm{Mn}$ applications raise the resistance of plants to drought stress (Khan et al., 2004; Movahhedy-Dehnavy et al., 2009). Otherwise, drought stress has exerted a negative effect on relative water content of leaves (RWC), and durum wheat under water stress loses much more water than the bread wheat. Larbi et al. (2004), Akram (2011) and Keyvan (2010) indicated that increase in the intensity of drought stress decreased RWC, total chlorophyll and increased proline content. Also, Tale \& Haddad (2011) stated that drought stress closes stomata, inhibits photosynthesis and damages the chlorophyll contents. Furthermore, Almeselmani et al. (2012) recorded reduction in all physiological traits, yield and yield component in

\#Corresponding author email: rasha.mahdy@aun.edu.eg

Received 09/11/2021; Accepted 10/1/2022

DOI : 10.21608/agro.2022.105221.1291

C2021 National Information and Documentation Center (NIDOC) 
the drought susceptible varieties compared to other varieties.

Foliar application of $\mathrm{Zn}, \mathrm{B}$, and $\mathrm{Mn}$ at booting to anthesis reduced the harmful effects of drought stress in winter wheat, and increased the rate of photosynthesis and chlorophyll content as measured by SPAD instrument, pollen viability, number of fertile spikes, number of grains per spike (Hassan et al., 2005; Karim et al., 2012; Tavallali et al., 2009). The sensitivity to $\mathrm{Zn}$ deficiency stress increased when plants were drought-stressed, and irrigation maximized grain yield with adequate supply of $\mathrm{Zn}$. Under drought stress the growth, yield, biochemical and antioxidant enzymes of the wheat plant were reduced (Bagci et al., 2007). However, application of salicylic acid or zinc has beneficial effects on growth and chemical constituents as well as yield quality under different levels of irrigation interval (Sofy, 2015). The foliar application of $\mathrm{Zn}$ alleviated the negative effects of drought stress (Hera et al., 2018; Yavas \& Unay, 2016) and improved yield and yield components (Sultana et al., 2016). Under salinity stress, it was found that foliar spraying with either $\mathrm{K}$ or Zn significantly increased yield and yield components (El-Dahshouri et al., 2017; Manal et al., 2016; Zafar et al., 2016). Likewise, foliar application of $\mathrm{Zn}$ increased SPAD and improved plant photosynthetic characteristics under water stress (Abid et al., 2018; Ma et al., 2017). Taran et al. (2017) showed that $\mathrm{Cu}$ and $\mathrm{Zn}$-nanoparticles alleviated the negative effect of drought action upon plants of winter wheat. In calcareous soil, $\mathrm{Ru}$ et al. (2018) indicated that $\mathrm{Fe}$ and $\mathrm{Zn}$ applications, either as soil or foliar application improved the grain yield, protein, and gluten content of wheat in calcareous soil. The aim of this work was to study the ability of foliar application of $\mathrm{Zn}$ to bread wheat to alleviate the effects of water stress and increase yield and yield components.

\section{Materials and Methods}

Two experiments were carried out during the two seasons; 2018/19 and 2019/20 at Faculty of Agriculture Experimental farm, Assiut University, Egypt (Longitude: $31.125^{\circ}$ Latitude: $27.25^{\circ} \mathrm{E}$, Elevation: $45 \mathrm{~m} / 148$ Feet). The soil texture is clay (Table 1). The first experiment was under drought stress, and the second one under normal irrigation with a stripe of six-meter width in between to prevent water seepage. The experimental design was split-plot in a randomized complete block design with three replications. The treatments of the whole plots were foliar spray of zinc oxide; 500ppm, 250ppm, water, and control (no treatment). The three cultivars were assigned to the split plots. The plot size was two rows, three $\mathrm{m}$ in long and $30 \mathrm{~cm}$ apart. Date of planting was November $28^{\text {th }}$ in the first and November $27^{\text {th }}$ in the second season. After full emergence the seedlings were adjusted to 30 seedlings per row. The two experiments were foliar sprayed two weeks before and at anthesis.

\section{The genetic materials}

The genetic materials were three spring wheat (Triticum aestivum L) Egyptian cultivars; Sakha 69, Giza 68 and Gemmieza 11.

\section{Irrigation}

The experiment under normal irrigation received planting irrigation and four surface irrigations throughout the growing season. However, the experiment under drought stress received planting irrigation and only one irrigation three weeks later.

TABLE 1. Some physical and chemical properties of representative soil samples in the experimental sites before sowing (30cm depth)

\begin{tabular}{|c|c|c|c|c|c|c|c|c|}
\hline Sand (\%) & Silt (\%) & Clay (\%) & $\begin{array}{l}\text { Texture } \\
\text { grade }\end{array}$ & $\begin{array}{c}\text { EC } \\
(1: 1 \text { extract }) \\
\text { dSm }^{-1} \\
\end{array}$ & pH & $\mathrm{CaCO}_{3}(\%)$ & $\begin{array}{c}\text { Organic } \\
\text { matter }(\%)\end{array}$ & $\begin{array}{c}\mathrm{NaHCO}_{3}^{-} \\
\text {extractable P } \\
\left(\mathrm{mg} \mathrm{kg}^{-1}\right)\end{array}$ \\
\hline 27.4 & 24.3 & 48.3 & Clay & 0.47 & 8.2 & 3.4 & 1.75 & 4.36 \\
\hline $\begin{array}{l}\text { Total } \\
\text { nitrogen }(\%)\end{array}$ & $\begin{array}{c}\mathrm{KCl}- \\
\text { extractable } \mathrm{N} \\
\left(\mathrm{mg} \mathrm{kg}^{-1}\right)\end{array}$ & $\begin{array}{c}\mathrm{Fe} \\
\mathrm{Mg} / \mathrm{kg}\end{array}$ & $\begin{array}{c}\mathrm{Mn} \\
\mathrm{Mg} / \mathrm{kg}\end{array}$ & $\begin{array}{c}\mathrm{Cu} \\
\mathrm{Mg} / \mathrm{kg}\end{array}$ & $\begin{array}{c}\mathrm{Zn} \\
\mathrm{Mg} / \mathrm{kg}\end{array}$ & $\begin{array}{c}\text { Soil moisture } \\
\text { at } \\
\text { F.Capacity. }\end{array}$ & $\begin{array}{c}\text { Soil moisture } \\
\text { at wilting } \\
\text { point. }\end{array}$ & $\begin{array}{c}\mathrm{NH}_{4} \mathrm{OAC}- \\
\text { extractable K } \\
\left(\mathrm{mg} \mathrm{kg}^{-1}\right)\end{array}$ \\
\hline 0.72 & 41.23 & 13.21 & 5.152 & 1.31 & 2.12 & $46 \%$ & $28 \%$ & 49.24 \\
\hline
\end{tabular}

* Each value represents the mean of three replications.

$\mathrm{Fe}, \mathrm{Mn}, \mathrm{Cu}$ and $\mathrm{Zn}$ were determined by inductively coupled plasma emission spectrometer (iCAP 6200) in the Central Lab of the Fac. of Agriculture.

Egypt. J. Agron. 43, No. 3 (2021) 


\section{Fertilization}

Super phosphate $\left(\mathrm{P}_{2} \mathrm{O}_{5}, 15.5 \%\right)$ was added during land preparation at a rate of $357.14 \mathrm{~kg} / \mathrm{ha}$. Nitrogen fertilization in the form of ammonium nitrate $(33.5 \% \mathrm{~N})$ was added to both experiments at a rate of $190.5 \mathrm{~kg} \mathrm{~N} / \mathrm{ha}$ in one dose before the first irrigation.

The soil moisture percentage (Table 2) at $30 \mathrm{~cm}$ depth in the drought stress experiment before anthesis was $23.86 \%$ in the first year and $18.52 \%$ in the second year, and was less than the wilting point $(28 \%)$ (Table 1). This indicates that the plants in the drought experiment were subjected to severe drought starting before anthesis to harvest.

To determine relative water content (RWC\%) five flag leaves were sampled at $0900 \mathrm{~h}$ in the morning at anthesis three days after the second spray of $\mathrm{Zn}$. The leaves were placed in polyethene bags and transferred to the laboratory as quickly as possible to minimize water losses. Fresh weight was determined one hour after excision. The turgid weight was obtained after soaking and incubating the leaves for $24 \mathrm{~h}$ in distilled water at $20^{\circ} \mathrm{C}$. After soaking, leaves were quickly and carefully blotted dry with tissue paper prior to the determination of turgid weight. Dry weight was obtained after oven-drying the leaf samples for $72 \mathrm{~h}$ at $70^{\circ} \mathrm{C}$. The relative water content was calculated from the equation: RWC\%= (fresh weight - dry weight $) /$ (turgid weight - dry weight) x100 (Larbi et al., 2004). A portable leaf chlorophyll meter (SPAD502; Konica Minolta Sensing, Inc., Japan) (The Soil Plant Analysis Development (SPAD) chlorophyll meter) was used to measure the leaf greenness of the plants 10 days before (75 days from sowing) and after anthesis (95 days from sowing) on 20 flag leaves from each plot. The strong relationship between readings of the portable SPAD-502 chlorophyll meter and leaf chlorophyll content has been demonstrated by several authors (Markwell et al., 1995; Marquard \& Tipton, 1987; Yadava, 1986).
At maturity, the plot (60 plants) was harvested, number of spikes/plant (NS/P), biological yield (BY/P, g), grain yield (GY/P, g) and 100 grain weight, $g(\mathrm{GW}, \mathrm{g})$ were recorded. Plant height $(\mathrm{PH}, \mathrm{cm})$ and spike length $(\mathrm{SL}, \mathrm{cm})$ were recorded on ten individual plants.

\section{Statistical analysis}

Statistical analysis was performed using Excel (Microsoft office 2016) on plot mean basis, and mean separation using LSD test according to Steel \& Torrie (1980).

\section{Results and Discussion}

The soil texture of the experimental site is clay, and the $\mathrm{pH}$ is 8.2 which could cause unavailability of $\mathrm{Zn}$ required for plant growth (Table 1). Zinc deficiency is most seen on alkaline and sandy soil. High levels of phosphorus and copper, and low level of nitrogen in the soil increase the probability of zinc deficiency. The availability of zinc to the plant decreases as $\mathrm{pH}$ increases (McKenzie, 2015; Wade, 2019). As pH rises, micronutrients precipitate as insoluble minerals, which cannot be taken up by plants.

Mean squares of $\mathrm{Zn}$ levels was significant $(\mathrm{P} \leq$ 0.05 or 0.01$)$ in both years and their combined under both environments for $\mathrm{PH}, \mathrm{NS} / \mathrm{P}, \mathrm{BY} / \mathrm{P}$, GY/P, RWC and chlorophyll at 75 and 95 days from sowing indicates the effects of $\mathrm{Zn}$ levels on all traits except SL (Tables 3 and 4). These results agree with those reported by Abid et al. (2018), Ma et al. (2017).

The effect of years under drought stress was significant $(\mathrm{P} \leq 0.01)$ for $\mathrm{PH}, \mathrm{GY} / \mathrm{P}$ and $\mathrm{GW}$. The differences among cultivars were significant $(\mathrm{P} \leq$ 0.01 ) either under drought or irrigated environment in all cases, except for yield under irrigation. This confirms the concept of selection for yield under stress is better than under favorable environment.

TABLE 2. The soil moisture percentage at $30 \mathrm{~cm}$ depth

\begin{tabular}{lccccc}
\hline & Seasons & \multicolumn{2}{c}{ Season 2018/19 } & \multicolumn{2}{c}{ Season 2019/20 } \\
\cline { 3 - 6 } Time & & $\begin{array}{c}\text { Drought stress } \\
\text { experiment }\end{array}$ & $\begin{array}{c}\text { Normal Irrig. } \\
\text { experiment }\end{array}$ & $\begin{array}{c}\text { Drought stress } \\
\text { experiment }\end{array}$ & $\begin{array}{c}\text { Normal } \\
\text { Irrig. } \\
\text { experiment }\end{array}$ \\
\hline Before $2^{\text {nd }}$ irrigation & 37.84 & 39.84 & 38.56 & 37.12 \\
${\text { Before } 4^{\text {th }} \text { irrigation }}_{\text {At anthesis }}$ & 23.86 & 33.72 & 22.81 & 36.89 \\
\hline
\end{tabular}




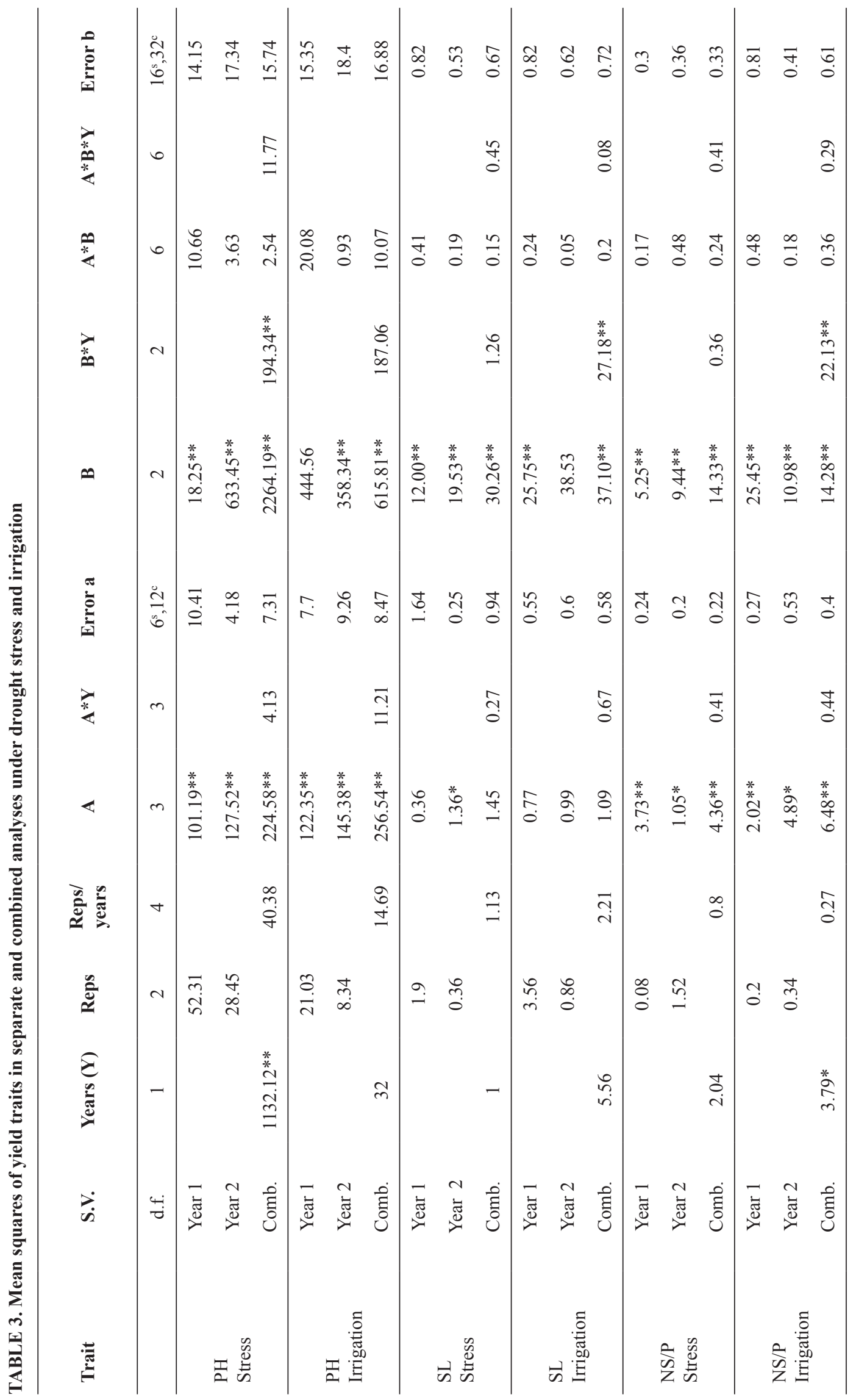

Egypt. J. Agron. 43, No. 3 (2021) 


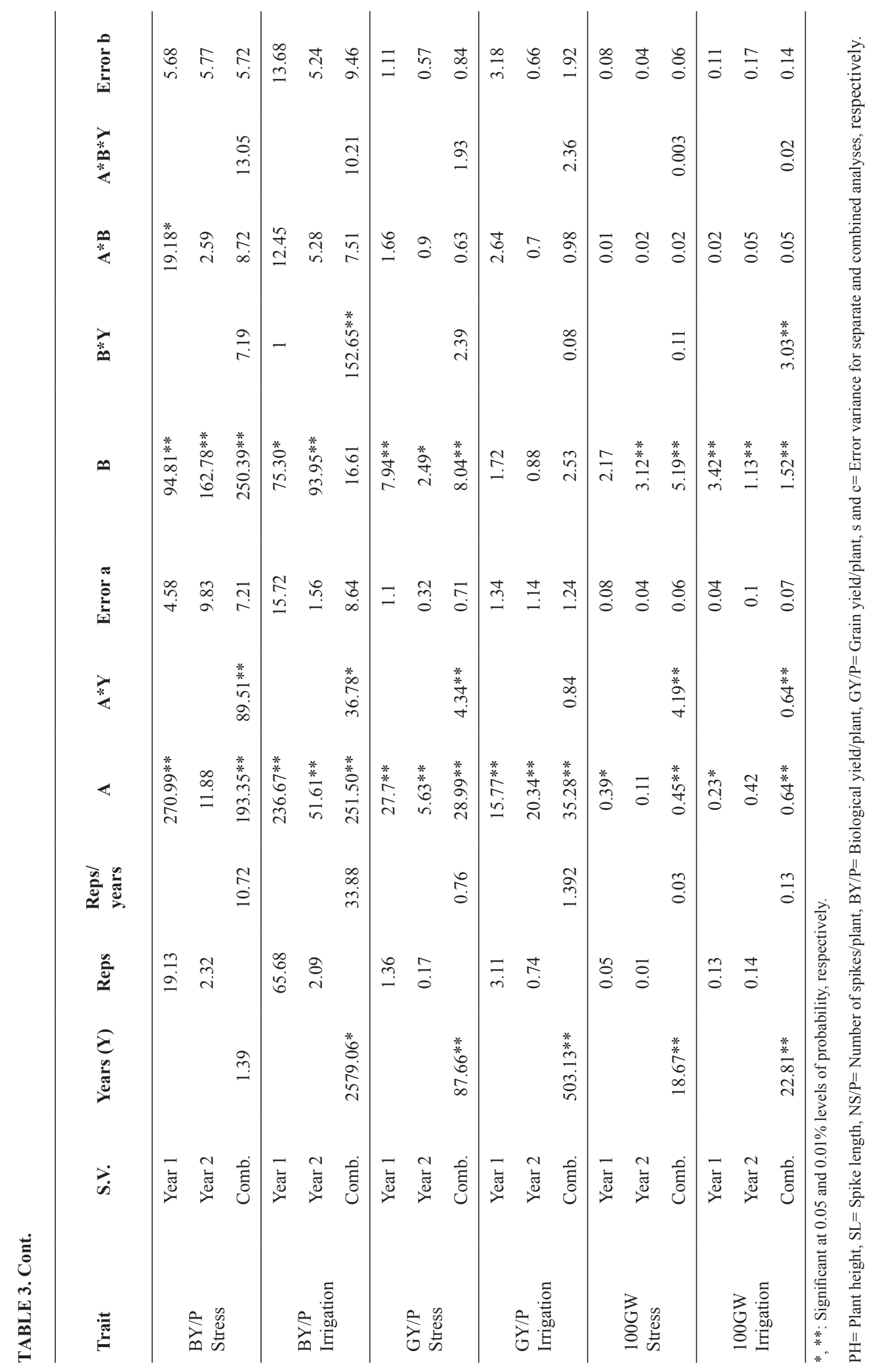

Egypt. J. Agron. 43, No. 3 (2021) 


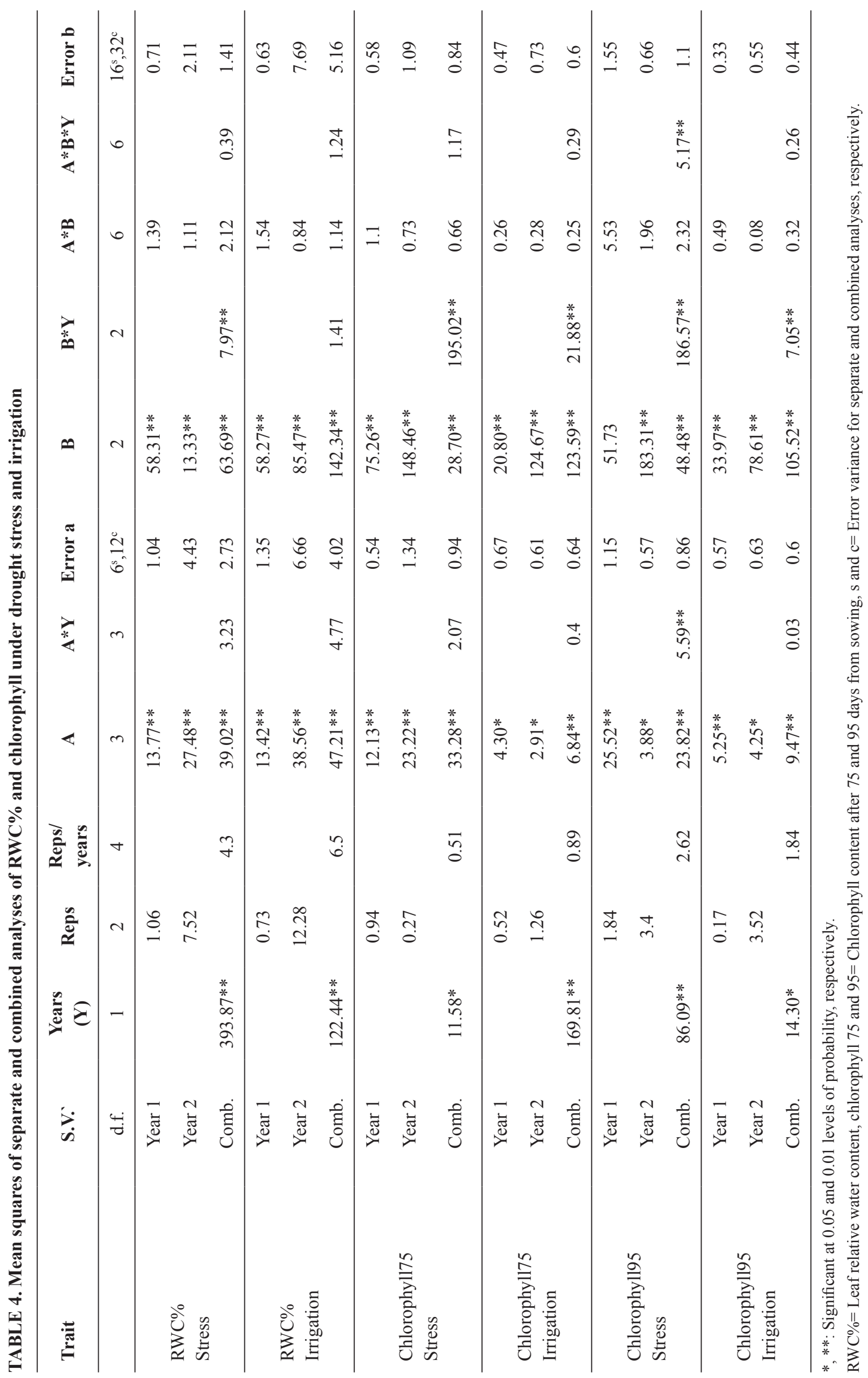

Egypt. J. Agron. 43, No. 3 (2021) 
Mean squares of RWC\% and chlorophyll before and at anthesis (Table 4) indicates the significant effect of years $(\mathrm{P} \leq 0.05-\mathrm{P} \leq$ $0.01)$. Furthermore, mean square of years for $\mathrm{RWC} \%$ and chlorophyll at anthesis (95 days) was larger under stress than under normal irrigation. The differences among $\mathrm{Zn}$ levels and among cultivars were significant $(\mathrm{P} \leq 0.01)$. The interaction of cultivars and years is significant except for $\mathrm{RWC} \%$ under normal irrigation, and mean squares of RWC\% and chlorophyll at anthesis was larger under drought stress than under normal irrigation. This preliminary study clarifies that selection among genotypes under drought stress for yield, RWC\% and chlorophyll content could be better than under normal irrigation.

Means of $\mathrm{PH}, \mathrm{NS} / \mathrm{P}, \mathrm{BY} / \mathrm{P}, \mathrm{GY} / \mathrm{P}$ and $100 \mathrm{gw}$ were the best at the higher $\mathrm{Zn}$ level $500 \mathrm{ppm}$ in both years and their combined (Table 5, Fig.1 to 6), while SL was not affected.

Water deficit exerted negative effects on RWC\% and chlorophyll at 75 and 95 days from planting in both years and their combined. The means decreased in descending order from $500 \mathrm{ppm}, 250 \mathrm{ppm}$, water and control (Fig.7 to 9). The combined mean of plant height under drought stress decreased from $88.22 \mathrm{~cm}$ to $79.86 \mathrm{~cm}$ at, and from 100.69 to $91.81 \mathrm{~cm}$ at $500 \mathrm{ppm} \mathrm{Zn} \mathrm{level} \mathrm{to} \mathrm{control} \mathrm{treatment}$ under normal irrigation and control treatment, respectively. The reduction $\%$ in all traits (Table 5, Fig. 10) was the lowest at $500 \mathrm{ppm}$ foliar application of $\mathrm{Zn}$ and increased in ascending order as level of $\mathrm{Zn}$ decreased. This indicates the ability of $\mathrm{Zn}$ foliar application to alleviate drought stress confirming the results of many researchers (Khan et al., 2004; Movahhedy-Dehnavy et al., 2009; Keyvan, 2010; Akram, 2011; Yavas \& Unay, 2016; Hera et al., 2018).

The combined means of the cultivars (Table 6) show that Sakha 69 significantly performed the best for NS/P and BY/P under both of drought stress and normal irrigation. Giza 168 showed the best performance in spike length, RWC\% and chlorophyll, and Gemmieza 11 was the best in GW under both environments. Respect GY/P Sakha 69 exceeded $(P \leq 0.05)$ the others under drought stress, however Gemmieza 11 was the best under normal irrigation in both years and combined. The reduction \% which reflects stability of the cultivars varied from trait to another, Sakha 69 showed the lowest Red\% (stable) in $\mathrm{PH}, \mathrm{BY} / \mathrm{P}, \mathrm{GY} / \mathrm{P}, \mathrm{RWC}$ and chlorophyll before and at anthesis (Fig. 11). Gemmieza 11 gave the lowest Red\% for SL. It could be concluded that Sakha 69 was the most stable cultivar in GY/P and out yielded the others under drought stress.

\section{Conclusion}

The availability of zinc to the plant decreases as $\mathrm{pH}$ increases. As $\mathrm{pH}$ rises, micronutrients precipitate as insoluble minerals, which cannot be taken up by plants. The $\mathrm{pH}$ of the experimental site was 8.2. Results indicated that mean squares of $\mathrm{Zn}$ levels was significant $(\mathrm{P} \leq 0.05$ or $0.01)$ in both years and their combined under both environments for $\mathrm{PH}, \mathrm{NS} / \mathrm{P}$, $\mathrm{BY} / \mathrm{P}, \mathrm{GY} / \mathrm{P}, \mathrm{RWC}$ and chlorophyll at 75 and 95 days from sowing indicating the effects of $\mathrm{Zn}$ levels on all traits except $\mathrm{SL}$. The differences among cultivars were significant $(\mathrm{P} \leq 0.01)$ either under drought or irrigation environment in all cases except yield under irrigation. This confirms the concept of selection for yield under stress is better than under favorable environment. Means of $\mathrm{PH}, \mathrm{NS} / \mathrm{P}, \mathrm{BY} / \mathrm{P}$, $\mathrm{GY} / \mathrm{P}$ and $100 \mathrm{gw}$ were the best at the high $\mathrm{Zn}$ level $500 \mathrm{ppm}$ in both years and their combined, while SL was not affected. The means decreased in descending order from $500 \mathrm{ppm}, 250 \mathrm{ppm}$, water and control. The reduction $\%$ in all traits was the lowest at $500 \mathrm{ppm}$ foliar application of $\mathrm{Zn}$ and increased in ascending order as level of $\mathrm{Zn}$ decreased. This indicates the ability of Zn foliar application to alleviate drought stress. It could be concluded that Sakha 69 was the most stable cultivar in GY/P and out yielded the others under drought stress. 


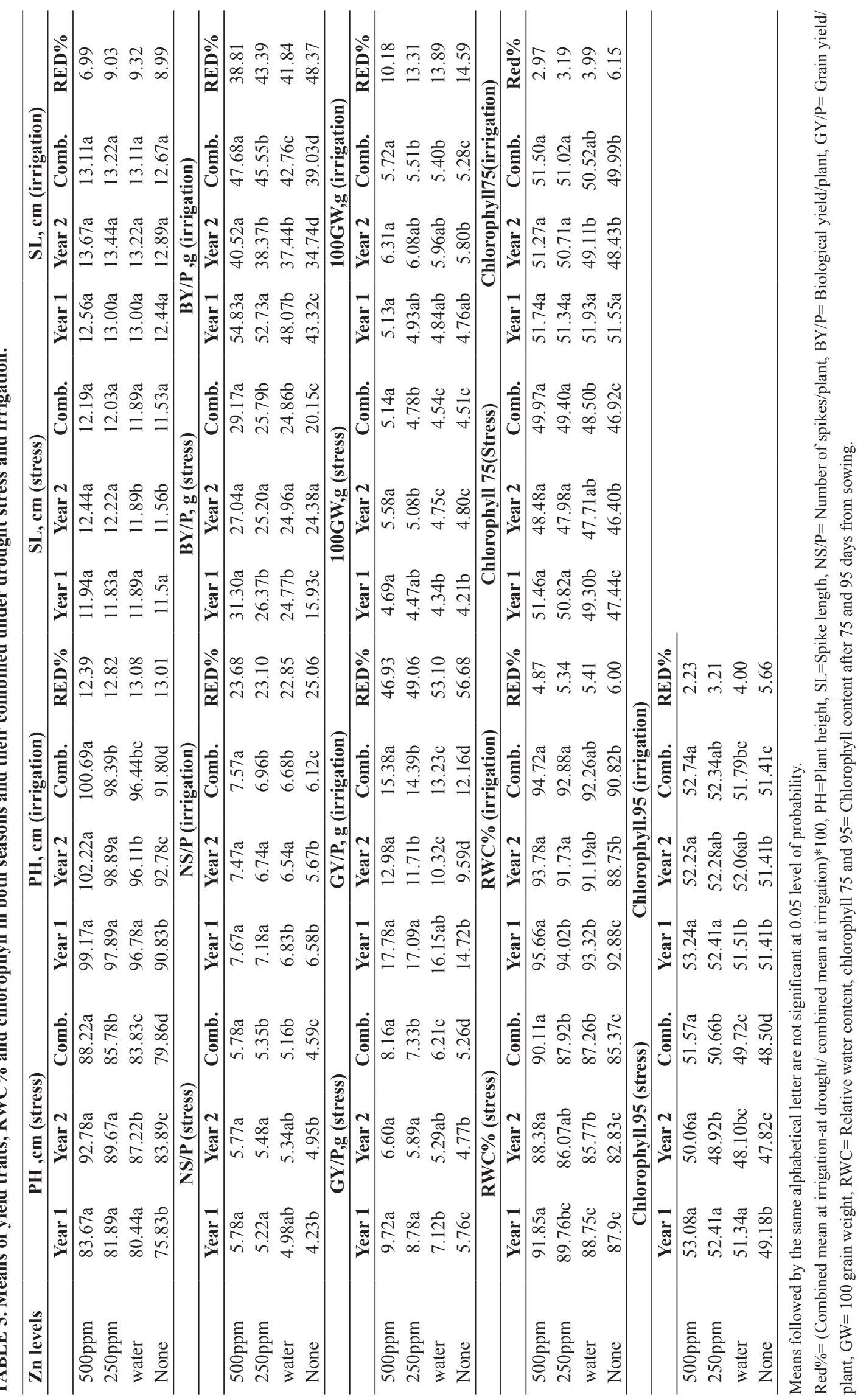

Egypt. J. Agron. 43, No. 3 (2021) 


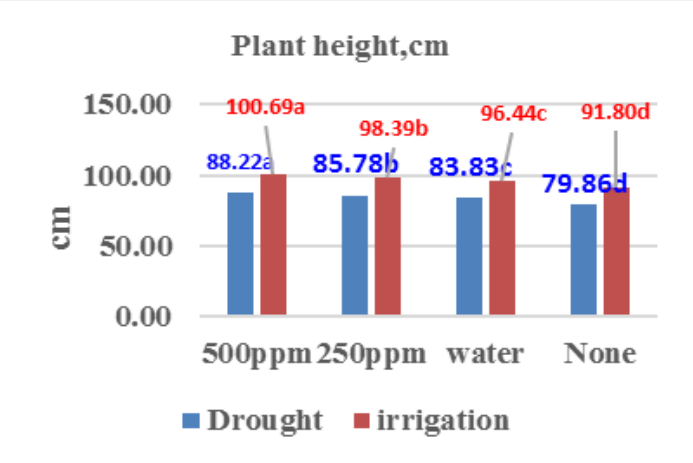

Fig. 1. Effect of zinc on PH (plant height, cm) based on combined means under drought and irrigation conditions [a, b means followed by the same letter are not significant under drought and irrigation separately]

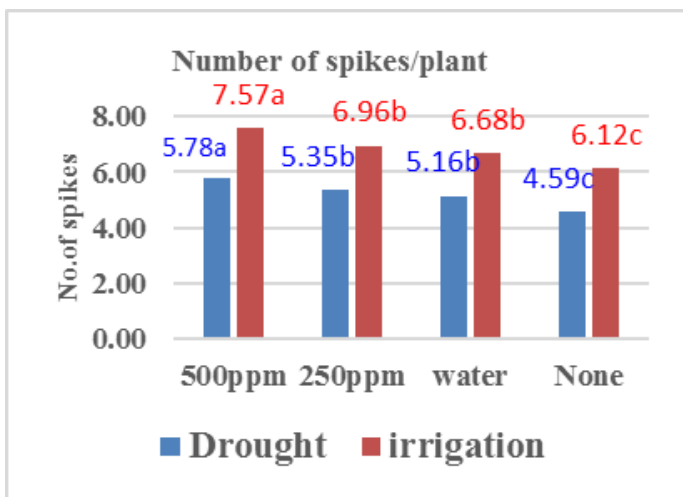

Fig. 3. Effect of zinc on NS/P based on combined means under drought and irrigation conditions $[a, b$ means followed by the same letter are not significant under drought and irrigation separately]

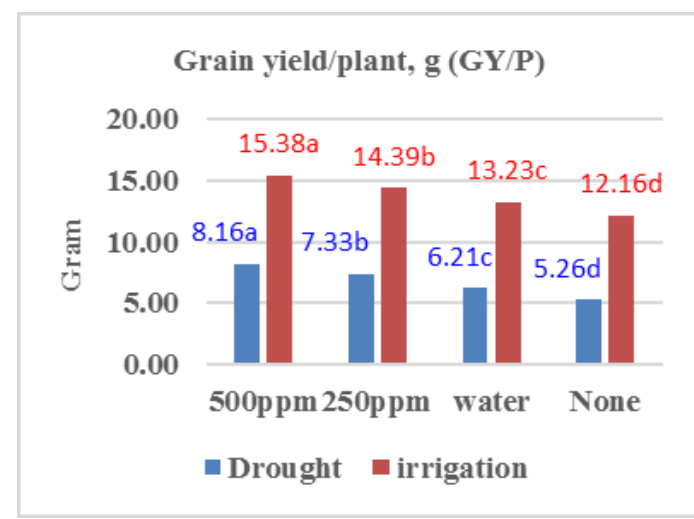

Fig. 5. Effect of zinc on GY/P based on combined means under drought and irrigation conditions [a, b means followed by the same letter are not significant under drought and irrigation separately]

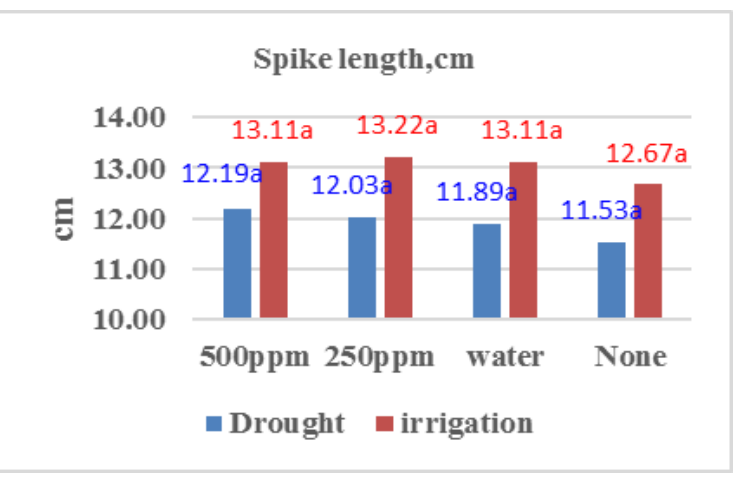

Fig. 2. Effect of zinc on spike length based on combined means under drought and irrigation conditions [a, b means followed by the same letter are not significant under drought and irrigation separately]

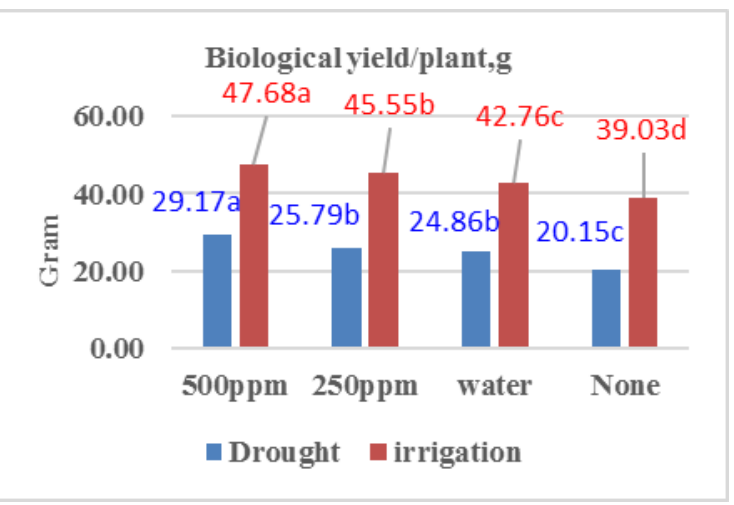

Fig. 4. Effect of zinc on BY/P based on combined means under drought and irrigation conditions [a, b means followed by the same letter are not significant under drought and irrigation separately]

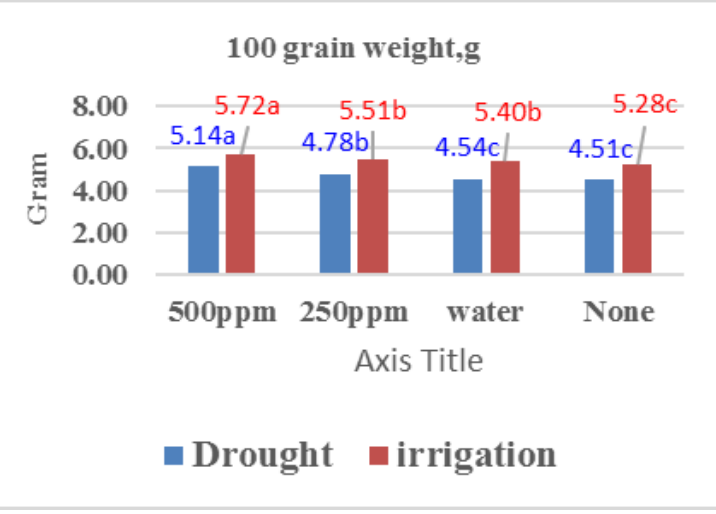

Fig. 6. Effect of zinc on 100 grain weight (g) based on combined means under drought and irrigation conditions [a, $b$ means followed by the same letter are not significant under drought and irrigation separately]

Egypt. J. Agron. 43, No. 3 (2021) 


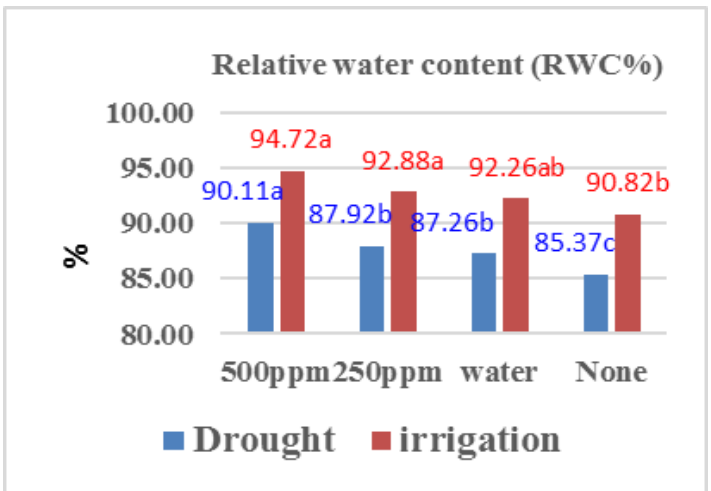

Fig. 7. Effect of RWC\% on PH based on combined means under drought and irrigation conditions [a, b means followed by the same letter are not significant under drought and irrigation separately]

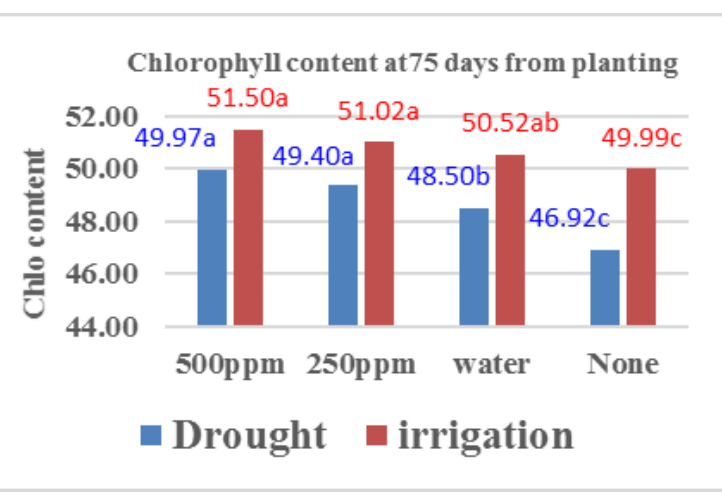

Fig. 8. Effect of zinc on (Chl.) chlorophyll 75d based on combined means under drought and irrigation conditions [a, b means followed by the same letter are not significant under drought and irrigation separately]

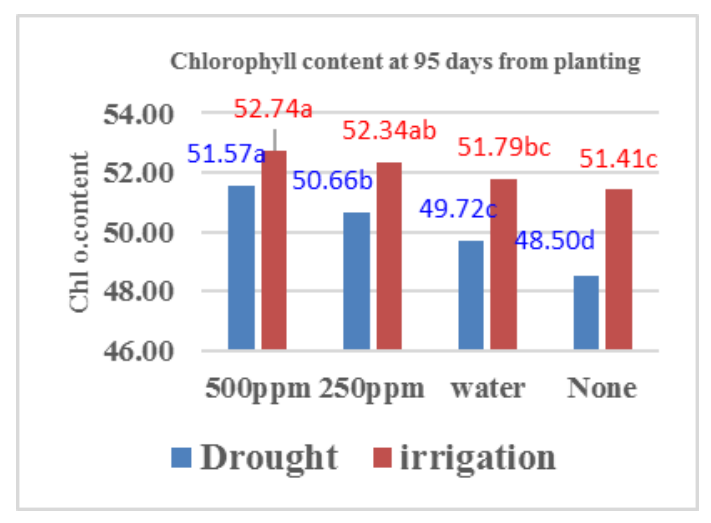

Fig. 9. Effect of zinc on (Chl.) chlorophyll 95d based on combined means under drought and irrigation conditions [a, b means followed by the same letter are not significant under drought and irrigation separately]

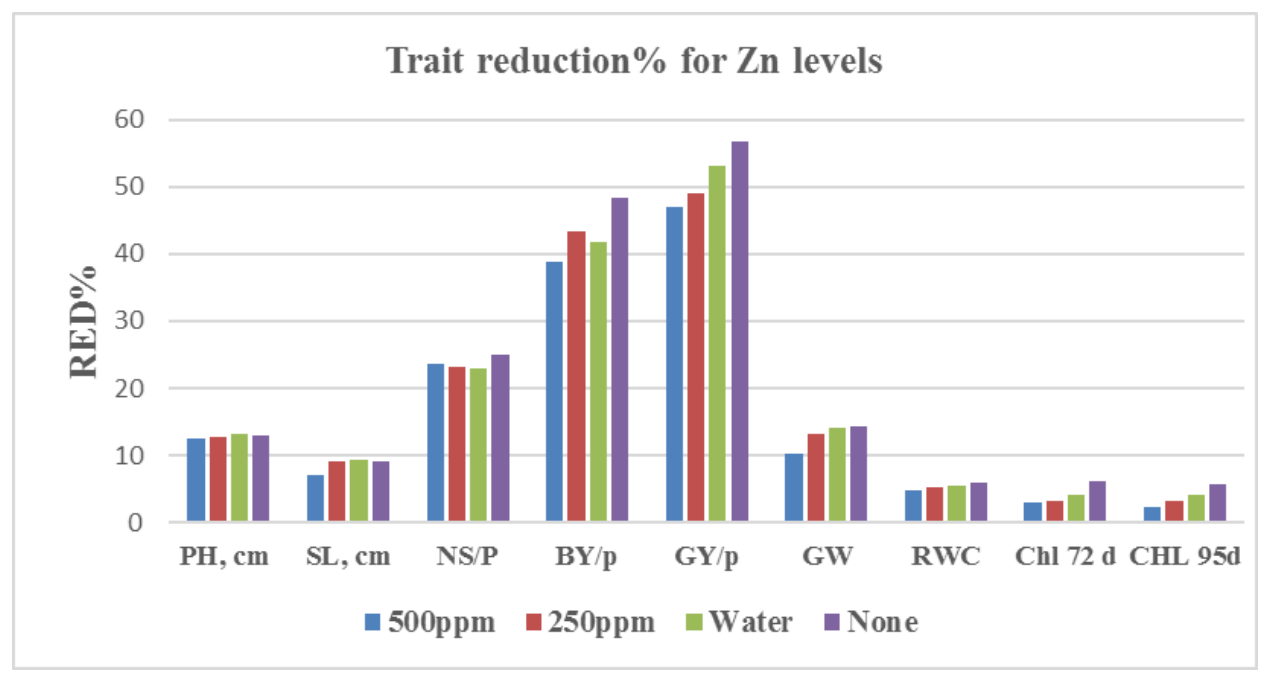

Fig. 10. Combined means of reduction \% in the studied traits over the two years for the $\mathrm{Zn}$ levels $[\operatorname{Red} \%=($ Combined mean at irrigation-at drought $/$ combined mean at irrigation) $* 100, \mathrm{PH}=\mathrm{Plant}$ height, $\mathrm{SL}=$ Spike length, $\mathrm{NS} / \mathrm{P}=$ Number of spikes/plant, $B Y / P=$ Biological yield/plant, $G Y / P=$ Grain yield/plant, $\mathbf{G W}=100$ grain weight, $R W C=$ Relative water content, chlorophyll 75 and $95=$ Chlorophyll content after 75 and 95 days from sowing]

Egypt. J. Agron. 43, No. 3 (2021) 


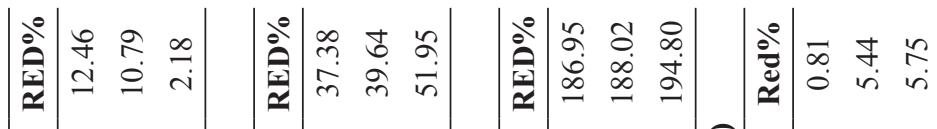

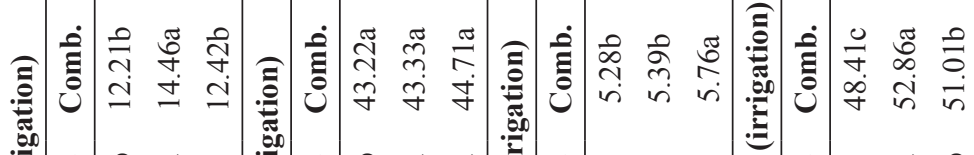

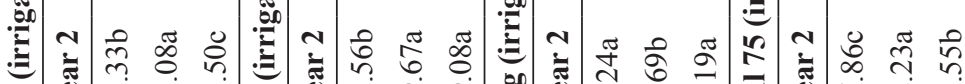

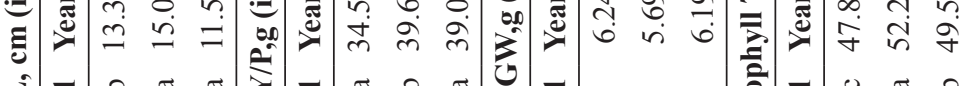

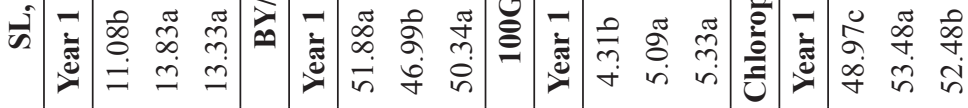

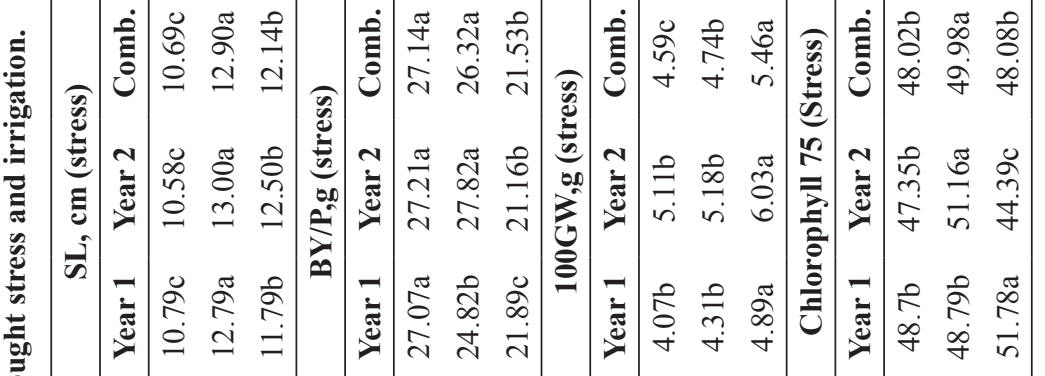

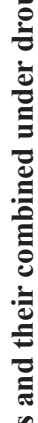

ปั้

苛

.

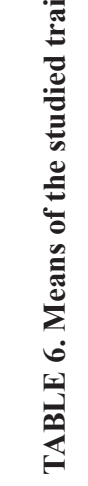

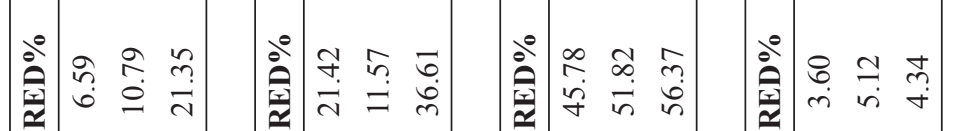

产 $\frac{\overline{0}}{2}$

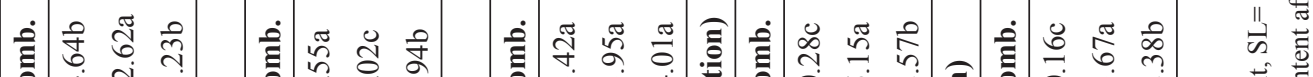

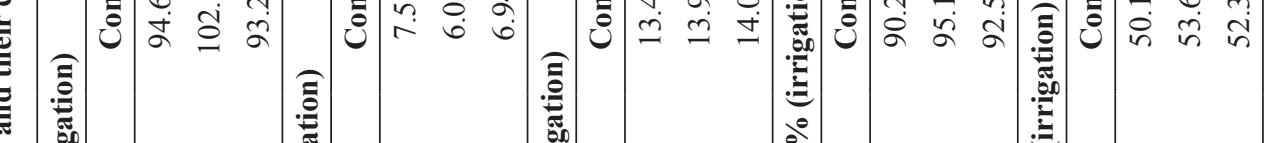
I छ

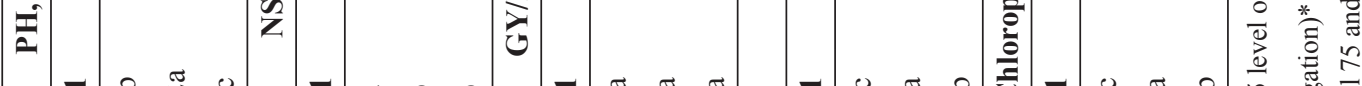

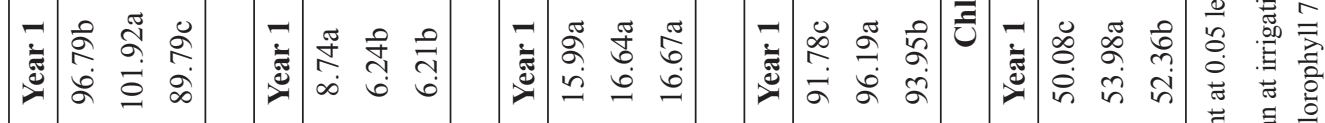
泀

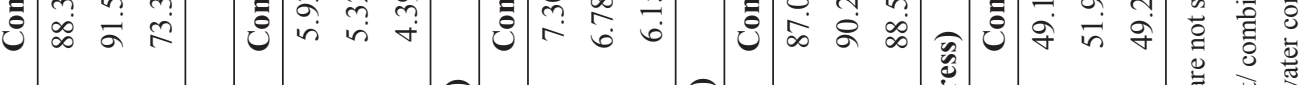

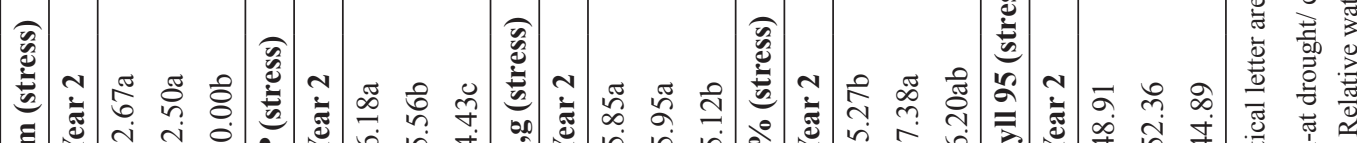
E 政

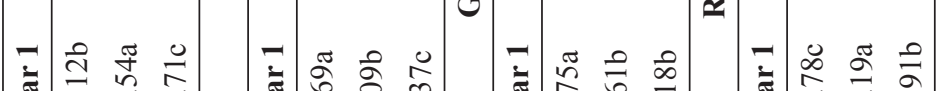

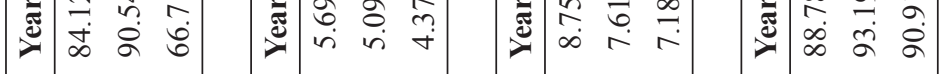




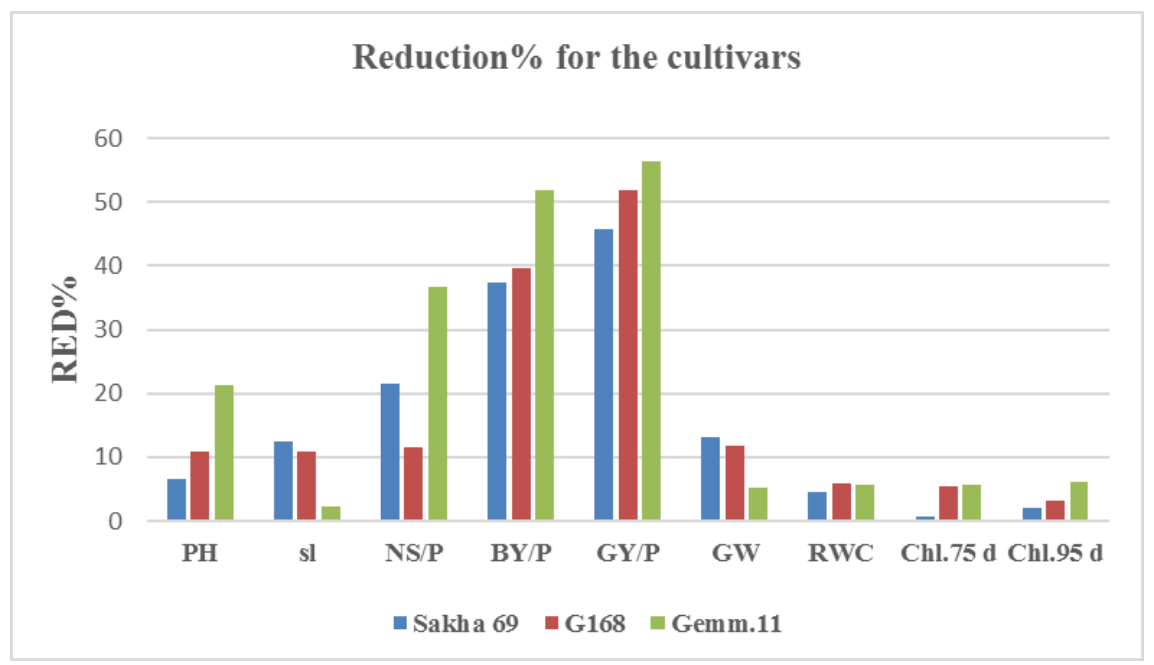

Fig. 11. Combined means of reduction $\%$ in the studied traits over the two years for the three cultivars [Red\%= (Combined mean at irrigation-at drought/ combined mean at irrigation)*100, PH= Plant height, $\mathrm{SL}=$ Spike length, NS/ $\mathrm{P}=$ Number of spikes/plant, $\mathrm{BY} / \mathrm{P}=$ Biological yield/plant, $\mathrm{GY} / \mathrm{P}=$ Grain yield/plant, $\mathbf{G W}=\mathbf{1 0 0}$ grain weight, $\mathrm{RWC}=$ Relative water content, chlorophyll 75 and $95=$ Chlorophyll content after 75 and 95 days from sowing]

\section{References}

Abid, M., Ali, S., Qi, L. K., Zahoor, R., Tian, Z., Jiang, D., et al. (2018) Physiological and biochemical changes during drought and recovery periods at tillering and jointing stages in wheat (Triticum aestivum L.). Scientific Reports, 8(1), 4615. https:// doi.org/10.1038/s41598-018-21441-7

Akram, M. (2011) Growth and yield Components of wheat under water stres. Bangladesh Journal of Agricultural Research, 36, 455-468.

Alloway, B.J. (2009) Soil factors associated with zinc deficiency in crops and humans. Environmental Geochemistry and Health, 31(5), 537-548.

Almeselmani, M., Saud, A.A., Al-zubi, K., Hareri, F., Al-nassan, M., Hareri, F., et al. (2012) Physiological attributes associated to water deficit tolerance of syrian durum wheat varieties. Experimental Agriculture \& Horticulture, 8, 21-41.

Bagci, S.A., Ekiz, H., Yilmaz, A., Cakmak, I. (2007) Effects of zinc deficiency and drought on grain yield of field-grown wheat cultivars in Central Anatolia. Journal of Agronomy and Crop Science, 193(3), 198-206.

Cakmak, I., McLaughlin, M.J., White, P. (2017) Zinc for better crop production and human health. Plant and Soil, 411(1-2), 1-4. https://doi.org/10.1007/

\section{s11104-016-3166-9}

El-Dahshouri, M.F., El-Fouly, M.M., Khalifa, R.K.M., El-Ghany, H.M.A. (2017) Effect of zinc foliar application at different physiological growth stages on yield and quality of wheat under sandy soil conditions. Agricultural Engineering International: CIGR Journal, 193, 193-200.

Hassan, M.J., Zhang, G., Wu, F., Wei, K., Chen, Z. (2005) Zinc alleviates growth inhibition and oxidative stress caused by cadmium in rice. Journal of Plant Nutrition and Soil Science, 168(2), 255261.

Hera, H.R., Hossain, M., Paul, A.K. (2018) Effect of foliar zinc spray on growth and yield of heat tolerant wheat under under water stress. International Journal of Bio-Resource and Stress Management, 1(1), 10-16.

Karim, M.R., Zhang, Y.-Q., Zhao, R.-R., Chen, X.P., Zhang, F.-S., Zou, C.-Q. (2012) Alleviation of drought stress in winter wheat by late foliar application of zinc, boron, and manganese. Journal of Plant Nutrition and Soil Science, 175(1), 142 151.

Keyvan, S. (2010) The effects of drought stress on yield, relative water content, proline, soluble carbohydrates and chlorophyll of bread wheat cultivars. Journal of Animal \& Plant Sciences, 8(3),

Egypt. J. Agron. 43, No. 3 (2021) 
1051-1060.

Khan, H.R., McDonald, G.K., Rengel, Z. (2004) Zinc fertilization and water stress affects plant water relations, stomatal conductance and osmotic adjustment in chickpea (Cicer arientinum L.). Plant and Soil, 267(1-2), 271-284.

Larbi, A., Mekliche, A., Agronomique, I.N., Phytotechnie, D.D. (2004) Relative water content ( RWC ) and leaf senescence as screening tools for drought tolerance in wheat. Growth (Lakeland), 196, 193-196.

Ma, D., Sun, D., Wang, C., Ding, H., Qin, H., Hou, J., et al. (2017) Physiological responses and yield of wheat plants in zinc-mediated alleviation of drought stress. Frontiers in Plant Science, 8, 1-12.

Mahpara, S., Hussain, S.T., Farooq, J. (2015) Drought tolerance studies in wheat (Triticum aestivum L.). Cercetari Agronomice in Moldova, 47(4), 133-140.

Manal, F.M., Thalooth, A.T., Amal, G.A. (2016) Performance of wheat plants in sandy soil as affected by foliar spray of potassium and zinc and their combination. International Journal of ChemTech Research, 9(07), 715-725.

Markwell, J., Osterman, J.C., Mitchell, J.L. (1995) Calibration of the Minolta SPAD-502 leaf chlorophyll meter. Photosynthesis Research, 46(3), 467-472.

Marquard, R.D., Tipton J.L. (1987) Relationship between extractable chlorophyll and an in-situ method to estimate leaf greenness. HortScience, 22, 1327:1327.

McKenzie, R. (2015) The broad basics of your soil's $\mathrm{pH}$. Retrieved from https://www.grainews.ca/ columns/the-broad-basics-of-your-soils-ph-2/

Moreno-Lora, A., Delgado, A. (2020) Factors determining $\mathrm{Zn}$ availability and uptake by plants in soils developed under Mediterranean climate. Geoderma, 376, 114509. https://doi.org/10.1016/j. geoderma.2020.114509

Movahhedy-Dehnavy, M., Modarres-Sanavy, S.A.M., Mokhtassi-Bidgoli, A. (2009) Foliar application of zinc and manganese improves seed yield and quality of safflower (Carthamus tinctorius L.) grown under water deficit stress. Industrial Crops and Products, 30(1), 82-92.

Nezhadahmadi, A., Prodhan, Z.H., Faruq, G. (2013) Drought tolerance in wheat. The Scientific World Journal, 3, 1-12. https://doi. org/10.1155/2013/610721

Ru, K., Hl, S., Kunjadia, B.B. (2018) Effect of zinc and iron application on leaf chlorophyll, carotenoid, grain yield and quality of wheat in calcareous soil of Saurashtra region. International Journal of Chemical Studies IJCS, 6(4), 2092-2096.

Sofy, M.R. (2015) Application of salicylic acid and zinc improves wheat yield through physiological processes under different levels of irrigation intervals. International Journal of Plant Research, 5(5), 136-156.

Steel, R.G.D., Torrie, J.H. (1980) Principles and procedures of statistics. In: "A Biometrical Approach", (2 $2^{\text {nd }}$ ed.). McGraw-Hill Book Company, New York.

Sultana, S., Naser, H.M., Shil, N.C., Begum, A.R. A. (2016) Effect of foliar application of zinc on yield of wheat. Bangladesh Journal of Agricultural Research, 41(2), 323-334.

Tale, A.S., Haddad, R. (2011) Study of silicon effects on antioxidant enzyme activities and osmotic adjustment of wheat under drought stress. Czech Journal of Genetics and Plant Breeding, 47(1), $17-27$.

Taran, N., Storozhenko, V., Svietlova, N., Batsmanova, L., Shvartau, V., Kovalenko, M. (2017) Effect of zinc and copper nanoparticles on drought resistance of wheat seedlings. Nanoscale Research Letters, 12(1). https://doi.org/10.1186/s11671-017-1839-9

Tavallali1, V., Rahemi1, M., Eshghi1, S., Kholdebarin, B.A.R. (2009) Zinc alleviates salt stress and increases antioxidant enzymeactivity in the leaves of pistachio (Pistacia vera L. 'Badami') seedlings. Turkish Journal of Agriculture and Forestry, 34(4), 349-359.

Wade, K.M. (2019) Diagnosing nutrient deficiencies and toxicities. PlantProbs.net.http:/plantprobs.net/ plant/nutrientImbalance/zinc.html.

Yadava, U.L. (1986) A rapid and nondestructive method to determine chlorophyll in intact leaves. 
HortScience, 21(6), 1449-1450.

Yavas, I., Unay, A. (2016) Effects of zinc and salicylic acid on wheat under drought stress. Journal of Animal and Plant Sciences, 26(4), 1012-1018.
Zafar, S., Ashraf, M.Y., Anwar, S., Ali, Q., Noman, A. (2016) Yield enhancement in wheat by soil and foliar fertilization of $\mathrm{K}$ and $\mathrm{Zn}$ under saline environment. Soil and Environment, 35(1), 46-55.

\section{دور الزنك فى تحمل الجفاف في القمح (تريتيكم استفم) تحث ظروف نقص الماء فى التربه

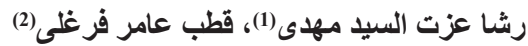

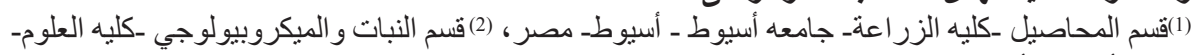

بؤثر الجفاف تأثثير خطير ا على انتاجيه الدحاصيل في مصر و العالم. أجريت تجربتين تحت ظروف الرئ الجفاف

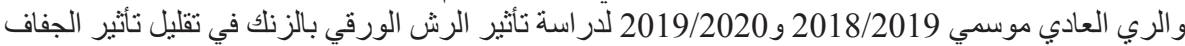

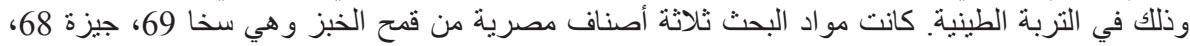

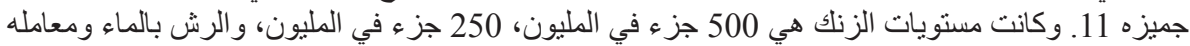

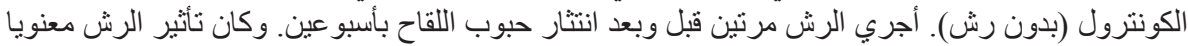

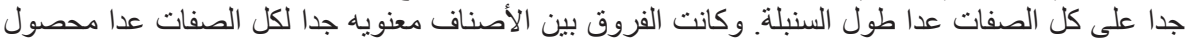

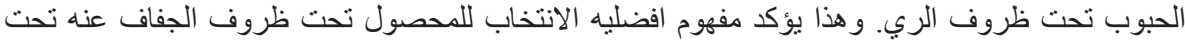

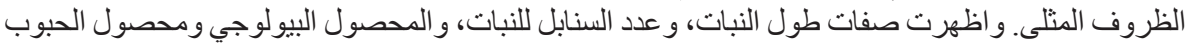

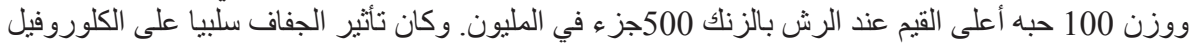

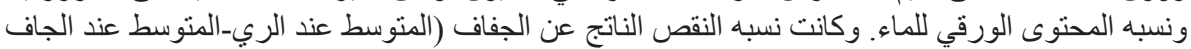

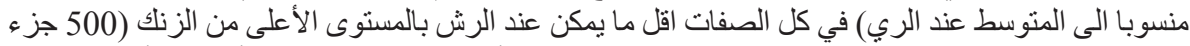

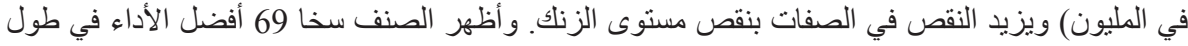

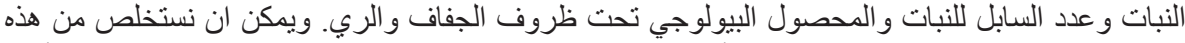

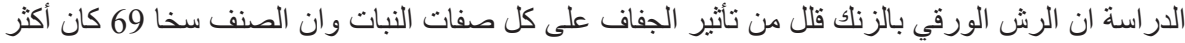

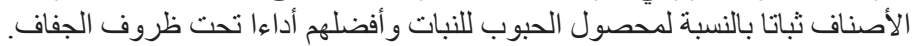

